\title{
Crystalline silicon solar cells with high resistivity emitter
}

\author{
P. PANEK, K. DRABCZYK*, and P. ZIĘBA \\ Institute of Metallurgy and Materials Science, Polish Academy of Sciences, \\ 25 Reymonta Str., 30-059 Cracow, Poland
}

\begin{abstract}
The paper presents a part of research targeted at the modification of crystalline silicon solar cell production using screen-printing technology. The proposed process is based on diffusion from $\mathrm{POCl}_{3}$ resulting in emitter with a sheet resistance on the level of $70 \Omega / \square$ and then, shaped by high temperature passivation treatment. The study was focused on a shallow emitter of high resistivity and on its influence on output electrical parameters of a solar cell. Secondary ion mass spectrometry (SIMS) has been employed for appropriate distinguishing the total donor doped profile. The solar cell parameters were characterized by current-voltage characteristics and spectral response (SR) methods. Some aspects playing a role in suitable manufacturing process were discussed. The situation in a photovoltaic industry with emphasis on silicon supply and current prices of solar cells, modules and photovoltaic (PV) systems are described. The economic and quantitative estimation of the PV world market is shortly discussed.
\end{abstract}

Keywords: crystalline silicon solar cells, industrial technology.

\section{Introduction}

The photovoltaics is one of the fastest-growing technologies in the world and photovoltaic (PV) industry shows remarkable progress due to increased world investment an estimated US\$ 10 billion in 2005 up from US\$ 7.5 billion in 2004 [1]. It resulted in 2004 module production $1.160 \mathrm{MWp}$ increased of $32 \%$ in 2005 to $1.532 \mathrm{MWp}$, which makes the total installed capacity is $3.7 \mathrm{GWp}$ of which $95 \%$ is on-grid PV systems [2]. Taking the lower reported value, the European installation are estimated at 650-680 MWp with over 600 MWp in Germany - the biggest PV market in EU [3]. In 2006, PV world business employed 12500 people.

In 2005, the world solar cells production by technology substrate types was the following, monocrystalline $\mathrm{Si}-$ $28 \%$, polycrystalline $\mathrm{Si}-56 \%$, amorphous $\mathrm{Si}-4 \%$, ribbon $\mathrm{Si}-3 \%, \mathrm{CdTe}-2 \%$, amorphous $\mathrm{Si}$ on $\mathrm{Cz}-\mathrm{Si}-7 \%$, so that the crystalline silicon captures around $91 \%$ share of the world photovoltaics market [4].

To satisfy the market demand, the three main trends exist nowadays in crystalline Si PV field:

- higher conversion efficiencies going from about $15 \%$ to $20 \%$ for the industrial cells,

- the use of thinner substrates, today 250-300 $\mu \mathrm{m}$ thin gradually is shifting to a thickness of 100-130 microns which determines the specific silicon consumption (SSC) per Watt peak (Wp) of solar electricity,

- growth of silicon supply.

While two first trends, connected with solar cells technology, are incontrovertible, the availability of suitable

\footnotetext{
*e-mail: kazimierz.drabczyk@wp.pl
}

solar grade silicon is the key constraint on the growth of PV. Table 1 shows the world production capacities of Si and what is more important, the announcement about the nearest planes in comparison with silicon for IC electronics [5].

Table 1. Current and predicted crystalline Si world production of raw material, solar cells and specific Si consumption trend in PV field (after Ref. 5).

\begin{tabular}{|c|c|c|c|c|}
\hline \multirow[b]{2}{*}{ Year } & \multicolumn{2}{|c|}{ Si production (MT/year) } & \multirow{2}{*}{$\begin{array}{c}\mathrm{SSC} \\
(\mathrm{g} / \mathrm{WP})\end{array}$} & \multirow{2}{*}{$\begin{array}{c}\text { Cell } \\
\text { production } \\
(\mathrm{MWp})\end{array}$} \\
\hline & $\begin{array}{c}\text { for IC } \\
\text { electronics }\end{array}$ & $\begin{array}{l}\text { for PV } \\
\text { sector }\end{array}$ & & \\
\hline 2004 & 18500 & 14300 & 13 & 1100 \\
\hline 2005 & 19500 & 16300 & 11 & 1500 \\
\hline 2006 & 20400 & 18850 & 10 & 1900 \\
\hline 2007 & 21400 & 29300 & 9.0 & 3250 \\
\hline 2008 & 22500 & 67500 & 8.5 & 7900 \\
\hline 2009 & 23600 & 86250 & 8.0 & 10800 \\
\hline 2010 & 24700 & 97800 & 7.5 & 13000 \\
\hline
\end{tabular}

Industry experts are now reporting a price of between 40 and 70 Euro/kg raw crystalline silicon in long contracts up to 10 years when up to 250 Euro/kg are even being paid on the spot market. The highly unusual development is noticed in China, where polycrystalline silicon production foreseen by 2010 should reach capacity of about 30000 MT/year [5].

The process of crystalline Si from ingot to the solar cell leads to the material losses. Heavily contaminated sides of the raw crystalline silicon ingots are sawn-off and this is the first loss of $\mathrm{Si}$, which equals approximately $15 \%$ up to $30 \%$ of its volume, but the removed $\mathrm{Si}$ is, in this case, recycled. 
Next, the blocks of crystalline Si are sliced into wafers using multi-wire saws and the highest losses occur during the wafering where about $40 \%$ of $\mathrm{Si}$ is lost as kerf and for the typical wafer $300-\mu \mathrm{m}$ thick at the present, the kerf loss is 180-200 $\mu \mathrm{m}$ [6]. The slurry is highly enriched with silicon, but there is no data, no knowledge viable process for recovery of the Si from cutting suspension. The mentioned preciously factor SSC takes into account the sawn-off, kerf and raw wafer Si material. The saw damage layer on both sides of wafer must be etched before the start of solar cell technology process, which reduces the wafer thickness to $280 \mu \mathrm{m}$. Considering the density of Si $2.328 \mathrm{~g} / \mathrm{cm}^{3}$ [7], one can calculate the yield in terms of a wafer surface area per ingot weight as $0.72 \mathrm{~m}^{2} / \mathrm{kg}$, so then the one $100 \mathrm{~cm}^{2}$ crystalline wafer must be more then Euro 1 per piece.

The $100 \mathrm{~cm}^{2}$ solar cell manufactured on the basis of this wafer from most producers has $15 \%$ conversion efficiency under standard test condition, i.e., light spectrum AM1.5G, normalized to $1000 \mathrm{~W} / \mathrm{m}^{2}$ and at temperature $25^{\circ} \mathrm{C}$. This means, that the cell shows the power of $1.5 \mathrm{Wp}$ which sets its market price. The average sales prices for the crystalline Si solar cells are on the level of 2.5 Euro/Wp, for the modules 3.5 Euro/Wp [8,9] while cell fabrication cost is about 0.3 Euro/Wp and module assembly 0.5 Euro/Wp [6].

The cost for the large-scale ground-based or roof-top turnkey systems with the crystalline silicon modules is about 5000 Euro/kWp [10]. The cost of the PV system including not only the module cost but also the balance of system (BOS) cost is summarized in Table 2 [3].

Table 2. Cost drivers for crystalline Si based photovoltaic system [3].

\begin{tabular}{l|c|c}
\hline The component parts of & & Cost \\
PV system & & \\
Modules & & $73 \%$ \\
\cline { 1 - 1 } $\begin{array}{l}\text { Substructure, framing, } \\
\text { installation }\end{array}$ & BOS & \\
DC-cabling & & $8 \%$ \\
Inverters & & $7 \%$ \\
Engineering & & $6 \%$ \\
Other (land area) & & $3 \%$ \\
\hline
\end{tabular}

The yield of PV systems, for example in Germany, which has average European solar irradiation of 1200 $\mathrm{kWh} / \mathrm{m}^{2}$ per year, achieves $1000 \mathrm{kWh}$ per one $\mathrm{kWp}$. The solar electricity price calculating, taking into account the PV system cost, its interest rate of $7.4 \%$ for the capital used, maintenance cost of $1.5 \%$ of the system cost and irradiation rate; for Germany gives 0.56 Euro per $1 \mathrm{kWh}$. This means, that the branch is still far away from achieving the residental grid prices which are between 0.1 Euro/kWh in Canada to 0.2 Euro/kWh in Denmark [10]. In order to reach grid parity at the price of conventional domestic electricity, the PV systems would have to cost around 1.5 Euro per $1 \mathrm{Wp}$ which is expected around 2020 by the simultaneous increase in conventional electricity price by $3 \%$ each year. Among other support mechanisms to promote PV a few countries implemented feed-in tariff, which is paid for solar electricity fed into the grid. The feed-in tariff in most cases depends on size of PV systems and for example in Euro per kWh is as follows, Germany - 0.51, Czech Republic - 0.46, Spain 0.44 , Austria - 0.6, and Italy - 0.49 [11].

\section{Experimental - crystalline silicon solar cells technology}

The emitter is the most important construction part of the crystalline silicon solar cell and its profile determines technology in the next steps as final electrical parameters and has decisive importance for solar cells direct manufacturing cost. The industrial production of solar cells requires chain process, consists of about 25 single process steps, dependent on a solar cell type and technology. However, the essential sequence can be presented in seven main steps which are given in Fig. 1. The solar cells are manufactured by most of the world companies according to this sequence. On this background, the technology elaborated at the Institute of Metallurgy and Materials Science (IMMS) for these particular steps is simple, inexpensive, verified and has a direct potential for mass scale application.

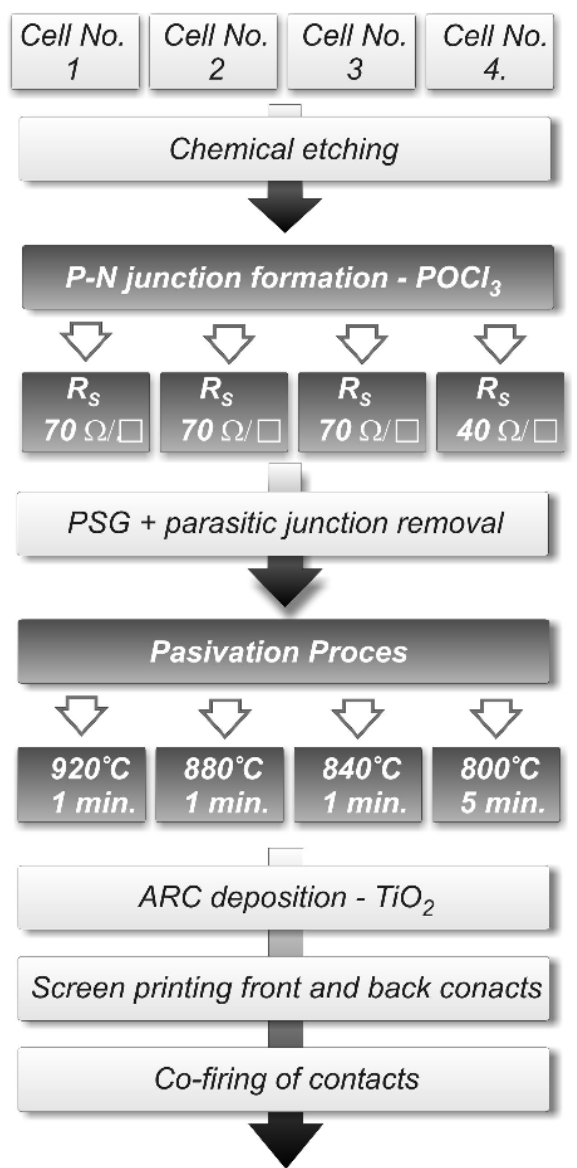

Fig. 1. Chart flow of screen printed contacts and co-fired metallization technology process of solar cells with different time of oxidation. 
All the samples were first etched in $\mathrm{KOH}(30 \%)$ to remove saw damage material $10-\mu$ m thick from each side of wafers and texturised in IPA: $\mathrm{KOH}(40 \%): \mathrm{DIH}_{2} \mathrm{O}$ in volume ratio $3: 1: 46$ solution at $80^{\circ} \mathrm{C}$ for 15 min and after that rinsed in $\mathrm{HCl}(2 \%)$ and $\mathrm{HF}(10 \%)$. All the chemical processes were completed by rinsing in deionised water and drying in $\mathrm{N}_{2}$.

The difference in our experiment is in diffusion and passivation temperatures which were applied in particular technological steps to monocrystalline $\mathrm{Si}(\mathrm{Cz}-\mathrm{Si})$, boron doped p-type, $1 \mathrm{ohm} \cdot \mathrm{cm}$ resistivity, 300- $\mu \mathrm{m}$ thick wafers and denoted as sample No. 1, 2, and 3. For the point of reference, the solar cell according to classical technology was prepared [12] and denoted as sample No. 4. The emitter for samples 1 , 2 , and 3 was generated at a temperature of $825^{\circ} \mathrm{C}$ for $25 \mathrm{~min}$ in an open quartz tube using liquid $\mathrm{POCl}_{3}$ as the doping source. In this process, a prediffusion duration time was 15 minutes while dopant redistribution time was 10 minutes which resulted in the emitter with a sheet resistance $70 \Omega / \square$. After diffusion, the parasitic junction was removed by means of a special Teflon clamp in which the wafers were immersed in $\mathrm{HNO}_{3}(65 \%): \mathrm{HF}(40 \%): \mathrm{CH}_{3} \mathrm{COOH}(80 \%)$ solution in the volume ratio 5:3:3 for $1 \mathrm{~min}$. Then, phosphorus silicate glass was removed by immersion in a bath of HF (10\%) for $2 \mathrm{~min}$.

For reference cell No. 4, the surface passivation was achieved by the growth of $\mathrm{SiO}_{2}$ at the temperature of $800^{\circ} \mathrm{C}$ for $15 \mathrm{~min}$ in a controlled $\mathrm{O}_{2}$ and $\mathrm{N}_{2}$ atmosphere and the value of $40 \Omega / \square$ of the sheet resistance which had been obtained after diffusion at $840^{\circ} \mathrm{C}$ for $30 \mathrm{~min}$ did not change. In the case of samples No. 1, 2, and 3 the silicon dioxide had been deposited for $5 \mathrm{~min}$ at $920^{\circ} \mathrm{C}, 880^{\circ} \mathrm{C}$, and $840^{\circ} \mathrm{C}$, respectively, which caused the change in sheet resistance and donor doped profile (see Table 3 and Fig. 2).

In this work, as the antireflection layer for solar cells, the titanium dioxide layer was deposited by CVD method with tetraethylorthotitanat $\left(\mathrm{C}_{2} \mathrm{H}_{5} \mathrm{O}\right)_{4} \mathrm{Ti}$ using purified nitrogen as a carrier gas. The liquid source $\left(\mathrm{C}_{2} \mathrm{H}_{5} \mathrm{O}\right)_{4} \mathrm{Ti}$ had vapoured at $200^{\circ} \mathrm{C}$ in a quartz bubbler and was transported via heated lines to a 5-mm diameter teflon nozzle located $10 \mathrm{~mm}$ above the silicon wafer heated at the temperature of $300^{\circ} \mathrm{C}$.

For the front contact, the Du Pont PV145 paste and for back contact the Ferro CN53-101 Al conductor paste were printed using 330 mesh screens and after drying at $150^{\circ} \mathrm{C}$ for $15 \mathrm{~min}$ the silicon wafers were co-fired in the IR conveyor furnace having $76-\mathrm{cm}$ long three zones heated sector and with $160 \mathrm{~cm} / \mathrm{min}$ belt speed.

\section{Measurements and results}

The I-V characteristics of solar cells were measured under standard conditions AM1.5 at a cell temperature of $25^{\circ} \mathrm{C}$ and the final data are shown in Table 3. A reference cell was calibrated at Wrocław University of Technology at the Photovoltaic Laboratory Solar Lab. using B-class Sun simulator.

Table 3. Main illuminated I-V parameters of solar cells in dependence on sheet resistance adequate to passivation temperature.

\begin{tabular}{cccccccc}
\hline $\begin{array}{c}\text { Cell } \\
\text { No. }\end{array}$ & $\begin{array}{c}\text { Passivation } \\
\text { temperature } \\
\left({ }^{\circ} \mathrm{C}\right)\end{array}$ & $\begin{array}{c}R_{\text {sheet }} \\
(\Omega / \square)\end{array}$ & $\begin{array}{c}I_{s c} \\
(\mathrm{~A})\end{array}$ & $\begin{array}{c}V_{\text {oc }} \\
(\mathrm{V})\end{array}$ & $\begin{array}{c}P_{m} \\
(\mathrm{~W})\end{array}$ & $F F$ & $\begin{array}{c}\mathrm{E}_{f f} \\
(\%)\end{array}$ \\
\hline 1 & 920 & 20 & 0.843 & 0.605 & 0.369 & 0.724 & 14.3 \\
2 & 880 & 40 & 0.888 & 0.605 & 0.402 & 0.749 & 15.6 \\
3 & 840 & 56 & 0.876 & 0.601 & 0.395 & 0.751 & 15.3 \\
4 (ref.) & 800 & 40 & 0.839 & 0.594 & 0.370 & 0.743 & 14.4 \\
\hline
\end{tabular}

where $R_{\text {sheet }}$ is the sheet resistance of an emitter, $I_{s c}$ is the short circuit current, $V_{o c}$ is the open circuit voltage, $P_{m}$ is the power in the optimum point, $F F$ is the fill factor, and $E_{f f}$ is the conversion efficiency.

The measured I-V curves of a solar cell were described by double exponential model (DEM) [13], defined as follows

$$
\begin{aligned}
I= & I_{p h}-I_{s 1}\left[\exp \left(\frac{V+I \cdot R_{s}}{A_{1} V_{t}}\right)-1\right] \\
& -I_{s 2}\left[\exp \left(\frac{V+I \cdot R_{s}}{A_{2} V_{t}}\right)-1\right]-\frac{V+I \cdot R_{s}}{R_{s h}}
\end{aligned}
$$

where $R_{s h}$ is the shunt resistance, $R_{s}$ is the series resistance, $I_{p h}$ is the photocurrent, $I_{s 1}$ is the first diode saturation current from the thermal generation of minority carriers within emitter and base regions, $I_{s 2}$ is the second diode saturation current from generation-recombination in space charge region, $A_{1}$ and $A_{2}$ are the diode ideality factors, $V_{t}$ is equal to $\mathrm{kT} / \mathrm{e}$ where $k, e$, and $T$ have their usual meaning.

The numerical fitting was carried out by SolarFit v1.8 computer program developed at Wrocław University of Technology at the Photovoltaic Laboratory Solar [14]. The values of parameters obtained by fitting the light $\mathrm{I}-\mathrm{V}$ curves of the described solar cells to the double diode model DEM

Table 4. Solar cell parameters determined from fit of the two-diode model to the illuminated I-V characteristics described in Table 3.

\begin{tabular}{cccccccc}
\hline Cell No. & $\begin{array}{c}I_{p h} \\
(\mathrm{~A})\end{array}$ & $\begin{array}{c}R_{s h} \\
(\mathrm{k} \Omega)\end{array}$ & $\begin{array}{c}R_{s} \\
(\mathrm{~m} \Omega)\end{array}$ & $\begin{array}{c}I_{s 1} \\
(\mathrm{~A})\end{array}$ & $\begin{array}{c}j_{s 1} \\
\left(\mathrm{~A} / \mathrm{cm}^{2}\right)\end{array}$ & $\begin{array}{c}I_{s 2} \\
(\mathrm{~A})\end{array}$ & $\begin{array}{c}j_{s 2} \\
\left(\mathrm{~A} / \mathrm{cm}^{2}\right)\end{array}$ \\
\hline 1 & 0.843 & 0.0198 & 18.7 & $2.66 \mathrm{e}-11$ & $1.04 \mathrm{e}-16$ & $2.97 \mathrm{e}-6$ & $1.16 \mathrm{e}-11$ \\
2 & 0.872 & 0.0438 & 10.7 & $2.91 \mathrm{e}-11$ & $1.16 \mathrm{e}-16$ & $2.97 \mathrm{e}-6$ & $1.19 \mathrm{e}-11$ \\
3 & 0.869 & 0.0589 & 10.1 & $3.06 \mathrm{e}-11$ & $1.23 \mathrm{e}-16$ & $3.99 \mathrm{e}-6$ & $1.59 \mathrm{e}-11$ \\
4 (ref.) & 0.826 & 0.0375 & 13.5 & $3.37 \mathrm{e}-11$ & $1.35 \mathrm{e}-16$ & $3.54 \mathrm{e}-6$ & $1.42 \mathrm{e}-11$ \\
\hline
\end{tabular}


are summarized in Table 4. The sheet resistance was measured by four-point probe technique.

It is interesting to compare cells No. 2 and 4 (ref.) having the same value of $R_{\text {sheet }}$ but obtained by the processing at different temperatures. It can be seen that the major difference is a significant increase of $I_{s c}$ and $V_{o c}$ for cell No. 2 with respect to the reference cell.

In Table 3, one can see that the best $I_{s c}$ shows the cell passivated at $880^{\circ} \mathrm{C}$ and further temperature lift, reducing the $R_{\text {sheet }}$, is not profitable for $I_{s c}$. The second most important parameter for the solar cell $V_{o c}$, consequently increased together with a passivation temperature which can be attributed to the increase in the active $P$ elements with reduction of material defects in Si crystal lattice. It is further interesting to note that the first diode saturation current diminution while the temperature of passivation increases. For the studied samples, the dopant concentration at the surface after the first step diffusion process is about $1 \times 10^{23}$ atoms $/ \mathrm{cm}^{3}$ (Fig. 2). Depending on the passivation temperature, a sheet resistance changes in the range from 20 to $56 \Omega / \square$. Along with the increase in the passivation temperature, sheet resistance falls, which is clear and does not require any further explanation. Important thing is that the highest dopant concentration at the surface is for the sample showing the highest sheet resistance. With the increase in passivation temperature, the series resistance increases too. This tendency results in the decrease of $F F$ and in a consequence makes ohmic contact between emitter and front metalisation difficult. The effect can be seen in $E_{f f}$ values. Solar cell of the lowest sheet resistance and the highest series resistance has the lowest value of the fill factor $F F$, and thus the lowest energy conversion efficiency $E_{f f}$.

According to the correlation between $R_{s}$ and $R_{s h}$, the lowest value of $F F$ has cell No. 1 passivated at a temperature of $920^{\circ} \mathrm{C}$.

Among other electronic devices, the distinguishing features of silicon solar cells are very shallow emitters, usually not exceeding $\sim 0.7 \mu \mathrm{m}$. The diffusion profiles presented in Fig. 2 were determined by the secondary ion mass spectroscopy (SIMS) measurements carried out with a Cameca IMS 6F SIMS spectrometer using cesium primary ions and the detection of 30Si31P negative secondary cluster ions. In Fig. 2, the profiles start from a value of $10^{15}$ atoms $/ \mathrm{cm}^{3}$ which is a bulk detection limit for $P$ elements in Si for SIMS method [7] but the real n-type doped Si is from $1.513 \times 10^{16}$ atoms $/ \mathrm{cm}^{3}$ corresponding to $1 \mathrm{ohm} \cdot \mathrm{cm}$ resistivity of p-type $\mathrm{Si}$ and this value is marked as doted horizontal line in Fig. 2.

In Fig. 2, on the axis of abscissae, the characterized point of emitter is laying in $\sim 0.12 \mu \mathrm{m}$ depth. After the passivation process, the original total phosphorus elements from a surface to this point are reduced whereas beyond it the concentration increases.

The spectral response was measured using a Jobi-Yvon H20 monochromator fitted with a 75-W tungsten-iodine lamp. The external quantum efficiency (EQE) of the silicon solar cells was measured with, calibrated by Hamamatsu Si S2281, photodiode and was calculated using its external

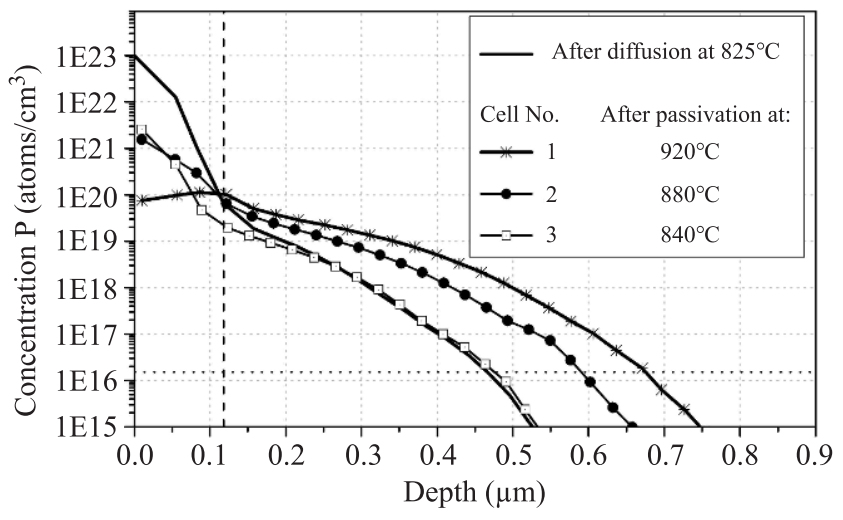

Fig. 2. Phosphorous concentration profile after diffusion determined by SIMS and its changes in relation to passivation temperature.

quantum efficiency. In Fig. 3, the dependences of EQE on a wavelength in the 400-600 nm range for samples No. 1, 2, and 3 are shown. The change in the shape of the emitter profile corresponds to the temperature of a second diffusion step taking place during passivation process. The dopant concentration decreases from the surface to the 1- $\mu$ m depth in bulk Si but deeper the $P$ elements concentration grows systematically.

Cells No. 2 and No. 3 exhibit a better short wavelength response as compared to cell No. 1. With respect to the better short wavelength response, it is apparent that the shallower profile of cell No. 3 results in less absorption within the highly recombinative emitter, and thus a higher collection probability for the short wavelength photons [15]. The degradation of the EQE observed in Fig. 3 is due to increasing passivation temperature and decreasing sheet resistance (see Table 3 ). The decrease in the surface concentration from $\sim 3 \times 10^{21}$ atoms $/ \mathrm{cm}^{3}$ for cell No. 3 to $\sim 1 \times 10^{20}$ atoms/ $\mathrm{cm}^{3}$ for cell No. 1 did not cause the EQE reduction in the near surface region. On the contrary, the EQE showed the best value level for cell No. 3 .

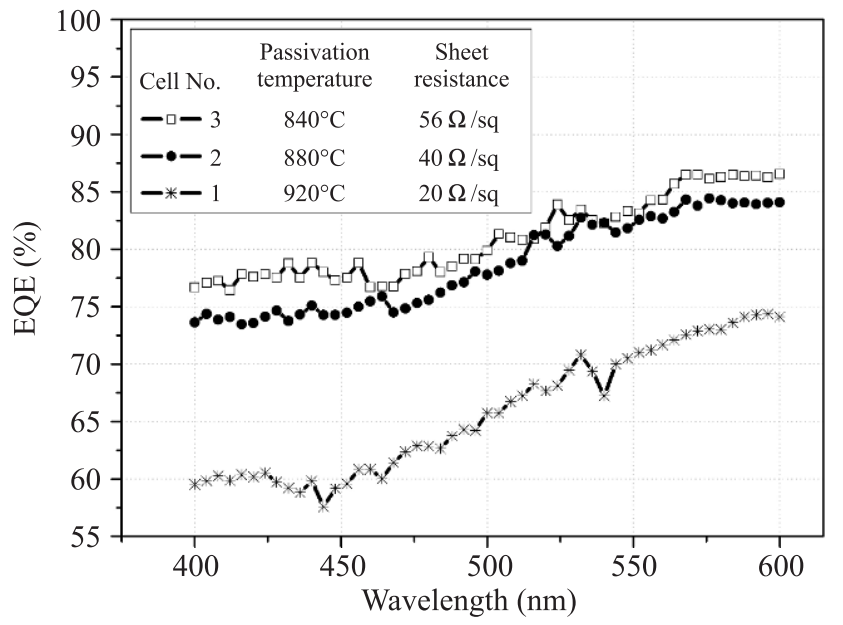

Fig. 3. External quantum efficiency for solar cells in dependence on passivation temperature and adequate value of a sheet resistance. 


\section{Conclusions}

The new approach of n-type emitter formation by double step process can be used on industrial level without any additional technological step. During the passivation process, taking place above the temperature of $840^{\circ} \mathrm{C}$, the shape of an emitter can be formed. The presented results indicate that the electrical parameters of the silicon solar cell depend mostly on the sheet resistance giving information about active $P$ elements but not directly on a dopant concentration at the surface region. The emitters with different profiles can be manufactured having the same sheet resistance. In the screen printing technology, obtaining the low resistivity ohmic contact between emitter and front metallization depends mostly on the concentration of a dopant at the surface. The screen-printed solar cells with dopant concentration profiles formed at lower temperatures of passivation process exhibit the higher fill factors $F F$. The presented double step process of formation of a dopant concentration profile in emitter allows the improvement in produced solar cells output parameters.

The solar cell obtained by the diffusion process at a temperature of $825^{\circ} \mathrm{C}$ and passivated at $880^{\circ} \mathrm{C}$ show the best electrical parameters and finally the best conversion efficiency which is associated with its emitter profile. It is possible to reduce the cost of a diffusion process by the lowering temperature of a process down to $825^{\circ} \mathrm{C}$, and shortening annealing time to 25 minutes.

\section{References}

1. E. Martinot, "Renewables global status update", Renew. Energ. World 9, 34-45 (2006).
2. W.P. Hirshman, "The envelope, please", Photon International 9, 143-146 (2006).

3. M. Bächler, "Thin future - outlook for grid-connected PV systems in Europe", Renew. Energ. World 4, 150-161 (2006).

4. P. Maycock and T. Bradford, "PV-market update", Renew. Energ. World 9, 68-81 (2006).

5. J. Bernreuter, "Full steam ahead from 2008", Sun \& Wind Energy 2, 92-104 (2006).

6. A. Cuevas, "Multicrystalline silicon: The photovoltaic material by excellence", Materials Forum 27, 1-8 (2004).

7. F. Shimura, Semiconductor Silicon Crystal Technology, Academic Press, p. 236, London, 1989.

8. W. Hirshman, "Shifting into a higher gear", Photon International 9, 140-141 (2006).

9. http://www.solarbuzz.com/moduleprices.htm

10. P. Welter, J. Siemer, and G. Hering, "Searching for the Holy Grail", Photon International 9, 160-163 (2006).

11. J. Bernreuter, "Critical mass", Sun \& Wind Energy 1, 93-101 (2006).

12. P. Panek, M. Lipiński, E. Bełtowska-Lehman, K. Drabczyk, and R. Ciach, "Industrial technology of multicrystalline silicon solar cells", Opto-Electron. Rev. 11, 269-275 (2003).

13. M. Lipiński and P. Panek, "Optimisation of monocrystalline silicon solar cell”, Opto-Electron. Rev. 11, 291-295 (2003).

14. T. Zdanowicz, "The interactive computer program to fit I-V curves of solar cells", Proc. $12^{\text {th }}$ European Photovoltaic Solar Energy Conf., Amsterdam, 1311-1314 (1994).

15. A. Bentzen, G. Schubert, J.S. Christensen, B. Svensson, and A. Holt, "Influence of temperature during phosphorus emitter diffusion from a spray-on source in multicrystalline silicon solar cell processing “, Prog. Photovolt.: Res. Appl. 15, 281-289 (2007). 